\title{
A PSZICHOLÓGIATÖRTÉNET-ÍRÁS PSZICHOLÓGIÁJA
}

Nem csupán a pszichológiatörténet és a történetírás természetét, de rejtetten tudományfilozófiai kérdéseket is feszeget $A$ humán tudományok alapkérdései illusztris sorozatában frissen megjelent kötet, A pszichológiatörténet-írás módszerei és a magyar pszichológiatörténet, Pléh Csaba, Mészáros Judit és Csépe Valéria szerkesztésében. A kötet önreflexív jellegét nem csupán a történeti perspektíva és a pszichológia önelemző természete adja, hanem az is, hogy a pszichológia mint terület kettősségeit - ami az elmélet-gyakorlat, kutatás-klinikum dichotómiákban szokott felmerülni - a pszichológia módszertani, kvantitatív-kvalitatív, hermeneutikai-naturalista, introspektív-objektivista kettőségein keresztül világítja meg. A pszichológiának mint tudományos megismerési és szemléletmódnak olykor terhe, olykor szabadsága, hogy egyszerre él benne a humán és a reál szempont. A kötet tanulmányai így izgalmas hossz- és keresztmetszetét adják a pszichológia tudásterületei történeti alakulásának különféle módszertani eszközzel: olvashatunk kvantitatív elemzést szövegbányászatról és képzési formákról, történeti és tényelemzést a pszichoanalízis vagy az alkalmazott pszicho-tudományok fejlődéséről és személyesebb hangvételű beszámolót az MTA Pszichológiai Kutatóintézetének belső életéről.

Pléh Csaba előszavában a pszichológiatörténet-írás kapcsán kétfajta szemléletmódra hívja fel a figyelmet: a történészi történetírásra, amely objektív képet kíván festeni és a pszichológusi történetírásra, amely értékel, és pályaszocializációs célokat is szolgál: kik a nagy személyiségek, miért és hogyan tűnt ki egy-egy labor, hogyan jött létre és miként müködött az oktatási-kutatási-képzési rendszer, mi az örökség? Vagyis a „Merre tartunk?” kérdésére is keresi a választ, amikor a „Honnan jövünk?”-ről gondolkodik, és követendő példákat és müködő mintákat igyekszik felmutatni. A pszichológia természeténél fogva azonban kettőnél valójában jóval többféle szemléletmód jelenik meg a kötetben, és bizonyos értelemben a pszichológiatörténet határait feszegeti, amikor sokféle megközelítésủ és tárgyú fejezetek kerülnek egymás mellé. A kötetet fö- és alfejezetek tagolják, de a tanulmányok rendre szétfeszítik e kereteket, engedetlenkedésük viszont nemcsak színessé teszi az anyagot, de fontos áthallásokat hoz létre, és éppen ez a széttartás mutatja meg, vagy inkább mutatja $f e l$, hogy milyen is a pszichológia: sok és sokféle szakmára, szemléletmódra, tevékenységi körre tagolódik.

Krimibe illő rémtörténetekkel, megrázó és tragikus életutakkal a kutatás, az oktatás és az egyetem, valamint a klinikum, a pszichoterápia, a pszichoanalízis és a rendelő világából is találkozhatunk. Enyhe eufemizmus a 20. század viharaiként utalni a fennhéjázó háborúskodás, az állami téboly, a bebörtönzések, a 
kényszervallatások, a morális és fizikai megsemmisítés és a folytonos újrakezdés történeteire, amelyek közepette bizonyos emberek feladatuknak nem a szomszéd feljelentését vagy a hatalom kiszolgálását, hanem az oktatást, a kutatást, a terápiát, a másik és a másmilyen ember felé fordulást tekintették. Illegális analitikusülések, kivégzett kollégák, elhurcolt vagy kitelepített nemzetközi szaktekintélyek sorában a magyar pszichológia története ugyanúgy bővelkedik, mint az országé. Ami érdekessé teszi ezt a történetet, hogy a szellemi tőke egy részét sikerült valahogy átmenteni a barbarizmus különféle rendszerei közepette: Mérei Ferenc WC-papírra írva, Falk Judit „egy-egy friss veknit” víve a mindig éhes diákoknak, többen a kutatásokat pavlovi, szovjet munkaköpenybe bújtatva, sokan ingyen vagy titokban dolgozva. Döbbenetes például, hogy a világhírü budapesti analitikus iskolát mindössze tizenhét fő vitte tovább 1945 után - de egyesületük már 1949-ben kénytelen volt feloszlatni önmagát (többek között az immár szovjet típusú antiszemitizmus fenyegetésére). Mérei Ferencnek legalább háromszor kellett újrakezdenie az életét és karrierjét. Harkai Schiller Pál, a magyar kísérleti pszichológia titánja, aki Wolfgang Köhlernél tanult Berlinben, és az első magyar pszichológiai intézetet huszonévesen szervezte meg, összehasonlító pszichológiai kísérletei mellett a hazai közvélemény-kutatások egyik elindítója is volt, 1947-ben a Columbia Egyetemre emigrált, de két évvel később, negyvenegy éves korában halálos síbaleset érte. Noha itthon jobbára ismeretlen, nemzetközi hírneve nemcsak a csimpánzok rajzolási képességeiről folytatott kutatásainak, de kollégájának, a neves Karl Lashley-nek is köszönhetö, aki több tanulmányát posztumusz kiadta - majd özvegyét is feleségül vette.

Az intézményesülés örök küzdelme szinte minden területén átíveli a magyar pszichológia történetét. Tudományosságára, módszereire nagy szüksége van a pedagógiának, de önállóságára gyakran nem; egyénre fókuszáló, hermeneutikai megközelítésére, az élményből kiinduló diagnosztikájára és emberközpontú terápiájára nagy szüksége van az orvostudománynak, de függetlenségére gyakran nem; intellektuális színességére, kutatási eredményeire, integratív inter- és multidiszciplináris jellegére nagy szüksége van a tudománynak, de saját hangjára gyakran nem. A fejezeteket áttekintve vitathatatlanul hatalmas eredményeket értek el az elödök, fáradtságot nem kímélve birkóztak a bürokráciával, a társszakmák irigységével, a belső viszályokkal: a saját tanszékek, az orvosival összehangolt klinikai képzési rendszer, a színes és a nemzetközi standardokhoz igazított terápiás módszerek elképesztő erőfeszítések révén legitimálódtak és stabilizálódtak. Szomorú látlelet, azonban egyfajta állandóság: száz éve is gyakran ingyen dolgoztak a fiatal oktatók és kutatók, és a költséges terápiás képzés gyakran ugyanolyan úri hóbort ma, mint volt egykor, az alkalmazott területeken sokszor éppen a tartalmi intervencióra nincs erőforrás. Ez a fajta szürés mind a mai napig felbecsülhetetlen károkat okoz. Diagnosztikai értékủ, hogy a sokszor átláthatatlan és szövevényes fokozatok és fokozatszerzési eljárások és történeti átalakulásuk külön fejezetet érdemelnek. 
A múlttal való szembenézés jelen idejü önvizsgálatra is felhív - a történelem nem ismerete nem mentesít annak hatálya alól.

A kötet tanulmányainak sora önelemzés abból a szempontból is, hogy a szerzők a múlt höseivel tükröt tartanak az olvasónak, de önmaguknak - és egymásnak is. Érdekfeszítő, de olykor lehangoló értesülni egy olyan világról, ahol a viták nem konstruktívak; mintha sem a tudományban, sem a gyógyításban nem számítana a tudományos standard, ami alapján megállapítható lenne egy klinikus vagy egy tudós munkájának értéke. Madártávlatból nézve nehezen érthetők a nagy analitikusok (mint Herman Imre és Szikáncs István között vagy Nemes Lívia és Hidas György között) és a nagy kutatók kibékíthetetlennek tűnő ellentétei (amely Czigler István és Erős Ferenc között a kötet lapjain is felparázslik). Mészáros Judit analitikus szemmel elemzi az analitikusokat: „A sohasem tisztázott konfliktusok feszültsége transzgenerációs úton továbbadódott a tanítványoknak...”, és „...lassan indultak el a »szeparációs-individualizációs « - leválási és új identitáskeresési folyamatok". Mintha az identitás és a szakmaiság között kellene választani; de hogy válhat hitelessé egy tudás-, tudós- és gyógyító közösség a kívülállók számára, ha valóban nincs közös szakmai szempont? Ha a széttartó módszertanokat és megközelítéseket sem a közös téma, az ember, sem a szereplök, a szakemberek nem tudják közös nevezöre hozni, vajon van-e közös története a pszichológiának? Kovai Melinda másik irányból, az alkalmazott ,pszicho-tudományok” pártállami történetén keresztül vet fel hasonló kérdéseket.

Az eredeti dokumentumokban bővelkedő kötet hiánypótló a magyar pszichológia történetét illetően, és diagnosztikai értékủ a jelenéről is. A szándékosan és a sorok között átadott tudás felelősséget ró az olvasóra, lehet-e jobban, lehet-e együtt? Vajon melyik lesz az első generáció, amelyik a szakterület közös ügyét az egyéni lavírozás fölé tudja helyezni, amelyik nem besimul, hanem alakít, amelyik át meri lépni a múlt és saját árnyékát? Ahogy Bárdos György tanár úr, az Eötvös Loránd Tudományegyetem kiváló oktatója fogalmazott: eljöhet-e a pszichológia évszázada?

(Pléh Csaba-Mészáros Judit-Csépe Valéria: A pszichológiatörténet-irás módszerei és a magyar pszichológiatörténet. [A humán tudományok alapkérdései] Budapest: Gondolat Kiadó, 2019, 492 o.)

Forgács Bálint PhD, Eötvös Loránd Tudományegyetem Kognitív Pszichológia Tanszék 